\title{
Role of soil in the life cycle of Meseres corlissi (Ciliophora: Oligotrichea): experiments with two clonal strains from the type locality, an astatic meadow pond
}

\author{
Helga Müller ${ }^{1, *}$, Wilhelm Foissner ${ }^{2}$, Thomas Weisse ${ }^{3}$ \\ ${ }^{1}$ Private Laboratory, Jacob-Burckhardt-Str. 18, 78464 Konstanz, Germany \\ ${ }^{2}$ University of Salzburg, FB Organismische Biologie, 5020 Salzburg, Austria \\ ${ }^{3}$ Institute for Limnology of the Austrian Academy of Sciences, Mondseestr. 9, 5310 Mondsee, Austria
}

\begin{abstract}
The life cycle of the oligotrich ciliate Meseres corlissi was investigated using 2 clonal strains, E4 and M10, which were isolated from soil samples collected at the type locality in Salzburg, Austria, and grown in a 1:1 mixture of WC medium and Eau de Volvic on a diet of cryptomonads. Growth, encystment, excystment and cyst survival of both strains depended strongly on the presence or absence of soil components in the culture medium. (1) Growth was enhanced greatly by addition of soil extract or sterilized garden soil. (2) Encystment could be induced by dilution of soil extract concentrations, whereas dilution of ciliates or food algae, at a constant soil extract level, had no significant effect. A sudden decrease in temperature, however, inhibited the encystment reaction. (3) Excystment could be triggered by addition of soil extract or sterilized garden soil. (4) Resting cysts survived desiccation periods of $>7 \mathrm{~d}$ only in the presence of sterilized garden soil. The nature of the 'soil factor' responsible for these effects remains at present unknown. The growth and encystment responses of strains E4 and M10 differ clearly from those of the earlier investigated strain DR (Weisse 2004), which was isolated from the reservoir of a tree bromelia in the Dominican Republic. These differences are interpreted as local adaptations of 2 morphologically and genetically indistinguishable but geographically distant populations of a cosmopolitan but rare ciliate species.
\end{abstract}

KEY WORDS: Meseres Corlissi $\cdot$ Soil $\cdot$ Encystment $\cdot$ Excystment $\cdot$ Local adaptation

\section{INTRODUCTION}

Ciliates of the class Oligotrichea can be found in water bodies of almost any kind and size, from ephemeric freshwater puddles and small tide-pools to large lakes and oceans. While resting cysts are known from several loricate and aloricate members of this group, the complete encystment-excystment cycle has been studied in only 4 species, namely Strombidium oculatum (Fauré-Fremiet 1948, Jonsson 1994, Montagnes et al. 2002), Helicostomella subulata (Paranjape 1980) and Cyrtostrombidium boreale (Kim et al. 2002) from marine waters, and Pelagostrombidium fallax (Müller 1996, 2002, Müller \& Wünsch 1999, Müller et al. 2002) from freshwater lakes. The polymorphic cycles of these species, though based on the same general pattern of alternating phases of population growth of active ciliates and dormancy of resting cysts, reveal adaptations to specific environmental situations. S. oculatum, living in tide-pools, is well known for its circatidal rhythm of en- and excystment, a strategy which obviously serves to retain the population in its pool during flooding by the high tide. The other 3 species, living in large water bodies, exhibit a pronounced seasonality of cyst formation, which may serve to survive periods of low food availability and/or high predation pressure as resting cysts. Two populations of $P$. fallax, in prealpine Lake Constance (Germany) and alpine Lake Mondsee 
(Austria), developed distinctly different seasonal patterns of cyst formation in response to the seasonal development of the entire plankton communities of these lakes. Excystment of $C$. boreale in a shallow marine bay (Onagawa Bay, Japan, depth $21 \mathrm{~m}$ ) was mainly controlled by mud temperature, which varied seasonally from 7 to $18^{\circ} \mathrm{C}$. P. fallax, in contrast, lives in deep lakes with little temperature variation at the lake bottom, and the most important factor controlling its excystment was cyst age. Cysts older than 3 mo excysted spontaneously at $4{ }^{\circ} \mathrm{C}$ in the dark, while a temperature stimulus was necessary to trigger excystment of younger cysts. These examples demonstrate the high flexibility of the encystment-excystment cycle within the class Oligotrichea.

The study object of the present investigation, Meseres corlissi Petz \& Foissner 1992 (Fig. 1), is an oligotrich freshwater ciliate closely related to the common Halteria grandinella. While both species are globally distributed, M. corlissi differs from $H$. grandinella inasmuch as it is a very rare ciliate, recorded from only a few sites. It was first found in a mud sample from an astatic meadow pond in Salzburg, Austria (Petz \& Foissner 1992). Further sporadic records (all by W. Foissner) are known from a pond in Kefermarkt near Linz, Austria, a salt-pan in the Etosha National Park, Namibia (Foissner et al. 2002), the Murray River flood plain, Australia, a flood plain in South East China, 4 sites from flood plains in Venezuela and Brazil, and the reservoir of a tree bromelia in a fog rain forest near Santiago, Dominican Republic. These sites, harbouring distinct, geographically distant populations of M. corlissi, are all small, ephemeric aquatic habitats. Cyst morphology of M. corlissi (Fig. 1) was studied in detail
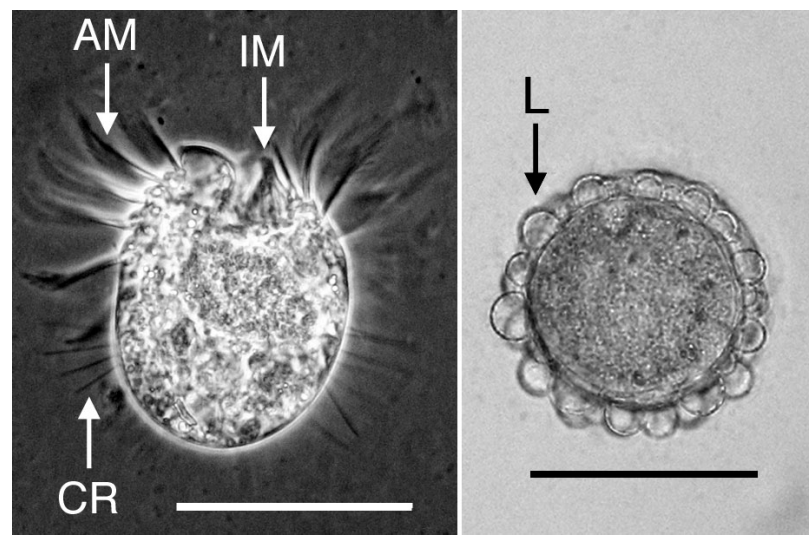

Fig. 1. Meseres corlissi. Live specimens, strain E4. Left: active. Right: encysted. Scale bars $=50 \mu \mathrm{m}$. AM: outer adoral membranelles; IM: inner adoral membranelles; CR: somatic ciliary row; L: extracellular organic scales, termed lepidosomes (for details see Foissner et al. 2005) by Foissner (2005) and Foissner et al. (2005) using material from Salzburg as well as from the Dominican Republic. These investigations reported that the specimens from the Dominican Republic are morphologically highly similar to those from the Austrian type population (Foissner et al. 2005). The species identity of the various Austrian clones and the isolate from the Dominican Republic was also confirmed using common molecular techniques (M. C. Strüder-Kypke unpubl.). The first ecological study of the species (Weisse 2004) was performed with an isolate from the bromelia population (Dominican Republic).

In the present study we investigated the life cycle of Meseres corlissi, using 2 clonal strains isolated from the type population in Salzburg. Since preliminary observations revealed strong effects of soil components on growth and survival of these strains, the study was focused on the impact of soil or soil extract in the culture medium on different phases of the life cycle. Our data represent the first ecological study of the complete encystment-excystment cycle of a halteriid ciliate. They will be used to compare ecological adaptations of 2 geographically distant populations of $M$. corlissi from different habitats, the reservoir of a tree bromelia (Weisse 2004) and an astatic meadow pond (present study).

\section{MATERIALS AND METHODS}

Origin of strains and maintenance of stock cultures. Two clonal cultures of Meseres corlissi, strain E4 and strain M10, were used in the present study. These strains were isolated from infusions of dry soil samples, which had been collected at the type locality, an astatic meadow pond in Salzburg, Austria (Petz \& Foissner 1992) in November 2002 and December 2003, respectively. Bacteria and nanoflagellates were present in these cultures. The species identity of the isolates was verified by morphological (Foissner 2005, Foissner et al. 2005) and genetic investigations (M. C. StrüderKypke unpubl.).

Stock and experimental cultures were maintained on a diet of Cryptomonas sp. (strain 26.80, Culture Collection of Algae, SAG, Göttingen, Germany). The food algae were grown in WC medium (Guillard \& Lorenzen 1972) at $10 \pm 1^{\circ} \mathrm{C}$ and white fluorescent light under a 14:10 h light:dark cycle ( 50 $\mu \mathrm{mol}$ photons $\left.\mathrm{m}^{-2} \mathrm{~s}^{-1}\right)$. Ciliate stock cultures were grown at $18 \pm 2^{\circ} \mathrm{C}$ and a 12:12 h light:dark cycle $\left(\sim 10 \mu \mathrm{mol}\right.$ photons $\left.\mathrm{m}^{-2} \mathrm{~s}^{-1}\right)$ in a 1:1 mixture of WC medium and Eau de Volvic (referred to as 'WC/Volvic' throughout this text) containing cryptomonads. Later on, when we understood the importance of soil for the strains under investigation, we added $10 \%$ of soil extract to the culture medium. 
Parallel cultures were maintained in biphasic medium containing sterilized garden soil (see below).

Details of culture techniques with soil and soil extract. We used a commercial garden soil containing no fertilizers or herbicides ('Qualitäts-Pflanzenerde', SagaFlor). Soil extract (SE) was prepared in 11 glass bottles. These were filled with soil up to the $800 \mathrm{ml}$ mark, and $700 \mathrm{ml}$ of deionized water was added. The bottles were autoclaved at $120^{\circ} \mathrm{C}$ for $30 \mathrm{~min}$, then again after $24 \mathrm{~h}$. The contents of the bottles were left to settle for at least $2 \mathrm{~d}$. Subsequently, the supernatant was decanted, filtered through a paper filter and distributed into $50 \mathrm{ml}$ bottles. These were autoclaved and stored at $4^{\circ} \mathrm{C}$ in the dark.

Batches of sterilized garden soil (SGS) were prepared in $100 \mathrm{ml}$ screw-top glass bottles. These were filled with dry soil, autoclaved twice at an interval of $24 \mathrm{~h}$ as described above, and stored at room temperature. For biphasic cultures, 6 to $8 \mathrm{~g}$ of dry SGS were introduced into $50 \mathrm{ml}$ tissue culture flasks with filter screw caps under sterile conditions by use of a broad forceps. After addition of 30 to $40 \mathrm{ml}$ of WC/Volvic containing cryptomonads, the bottles were ready for inoculation with ciliate strains.

Determination of cell concentrations. To determine concentrations of ciliates and algae in experimental cultures, 3 to $4.5 \mathrm{ml}$ subsamples were taken after thorough mixing and fixed with a drop of acid Lugol's solution. In a Sedgewick-Rafter chamber, $1 \mathrm{ml}$ aliquots were scanned for ciliates and suspended cysts. Cryptomonads were counted in the same chambers by scanning 5 to 10 randomly selected squares, i.e. 5 to $10 \mu$ of sample volume.

Total cyst numbers could not be determined by this method, since the majority of the cysts (generally 70 to $90 \%$ ) were firmly attached to the walls of the culture dishes. On one occasion (Expt 3, see below), a cell scraper was used to detach all cysts prior to sampling the culture fluid. Cysts attached to bottoms and edges of multiwell test plates (Expts 4 and 5, see below) were counted in situ under a microscope at $100 \times$ magnification. Cysts in biphasic cultures could not be quantified. They are almost impossible to detect, due to soil particles adhering to their mucous surface.

Live counts of active ciliates in multiwell test plates were performed under a dissecting microscope. When numbers exceeded 10 ciliates per well, counting was faciliated by transferring the ciliates, one by one, to a separate culture dish by use of a micropipette.

Expts 1 and 2. Growth with different concentrations of soil extract (SE). These experiments were performed in $50 \mathrm{ml}$ tissue culture flasks with filter screw caps. For Expt 1 we used a stock culture of strain M10 (52 ciliates $\mathrm{ml}^{-1}$ ) which had been cultivated in SE-free medium ever since its isolation from the natural soil sample. Three experimental bottles received $32 \mathrm{ml}$ each of WC/Volvic containing cryptomonads, $4 \mathrm{ml} \mathrm{SE}$ and $4 \mathrm{ml}$ of the ciliate stock culture. Three control bottles were prepared the same way, except that $4 \mathrm{ml}$ Volvic were added instead of SE. In experimental and control bottles, initial cell concentrations were 5 to 6 ciliates $\mathrm{ml}^{-1}$ and 6.5 to $6.8 \times 10^{4}$ cryptomonads $\mathrm{ml}^{-1}$ and the initial $\mathrm{pH}$ was 7.6 . The bottles were incubated at $22.5 \pm 1^{\circ} \mathrm{C}$ and a $12: 12$ light:dark cycle $(\sim 70 \mu \mathrm{mol}$ photons $\mathrm{m}^{-2} \mathrm{~s}^{-1}$ ) for $6 \mathrm{~d}$. Cell concentrations were determined 24, 74, 95 and $138 \mathrm{~h}$ after inoculation. On Day 4, additional $6 \mathrm{ml}$ subsamples were taken from each of the SE-containing cultures to start Expt 2. Each subsample served to inoculate a set of 3 new bottles (2 ml inoculate per culture) filled with $38 \mathrm{ml}$ of WC/Volvic containing 0,5 and $10 \%$ SE, respectively. Initial food concentrations were 7.2 to $8.0 \times 10^{4}$ cryptomonads $\mathrm{ml}^{-1}$. These cultures were incubated at the conditions described above; cell concentrations were determined 43, 65 and $113 \mathrm{~h}$ after inoculation. Growth rates $(\mu)$ for sampling intervals $(t)$ were calculated from initial $\left(N_{0}\right)$ and final $\left(N_{t}\right)$ cell concentrations determined at the start and end of $t$ according to: $\mu=\left(\ln N_{t}-\ln N_{0}\right) t^{-1}$.

Expt 3. Growth in the presence or absence of sterilized garden soil (SGS). This experiment was performed in cylinder-shaped glass dishes (height: $4 \mathrm{~cm}$; diameter: $5.5 \mathrm{~cm}$ ). In the center of 2 experimental dishes a glass cylinder (diameter: $3 \mathrm{~cm}$ ) filled with SGS was placed, the bottom of which was formed by a $20 \mu \mathrm{m}$ net (Fig. 2). Water-soluble substances as well as small organisms (i.e. bacteria and nanoflagellates) could freely pass the net, whereas the ciliates could not, due to their larger size. Two control dishes did not have this insert. Stock cultures of strain E4, maintained in biphasic medium, were used in this experiment. $50 \mathrm{ml}$ of supernatant (combined from 3 biphasic cultures) were diluted with $50 \mathrm{ml}$ of Cryptomonas culture,

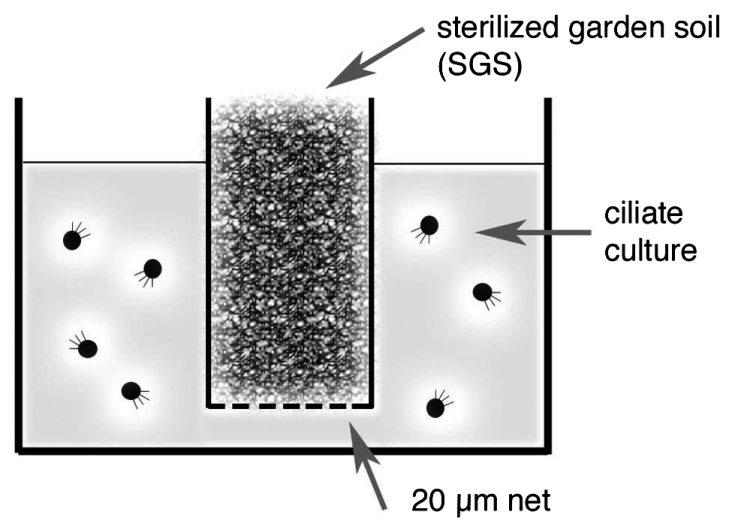

Fig. 2. Setup of Expt 3. Culture dish with SGS-containing cylinder 
$80 \mathrm{ml} \mathrm{WC/Volvic} \mathrm{and} 20 \mathrm{ml} \mathrm{SE}$, resulting in a $200 \mathrm{ml}$ mixture containing $10 \%$ SE. Each glass dish received $50 \mathrm{ml}$ of this mixture; subsequently $3 \mathrm{ml}$ subsamples were taken from each dish for cell counts. Initial cell concentrations were 48 to 61 ciliates $\mathrm{ml}^{-1}$ and 5.8 to $7.1 \times 10^{4}$ cryptomonads $\mathrm{ml}^{-1}$. The dishes were incubated at $19 \pm 1{ }^{\circ} \mathrm{C}$ and a $12: 12 \mathrm{~h}$ light:dark cycle $\left(\sim 10 \mu \mathrm{mol}\right.$ photons $\left.\mathrm{m}^{-2} \mathrm{~s}^{-1}\right)$. Changes in ciliate and algal concentrations were monitored over 6 d. On Day 6 , the cylinders were removed and all cysts adhering to the bottom and walls of the dish were detached by means of a cell scraper. After suspending the cysts in the culture fluid by thorough mixing, subsamples were taken and fixed with a drop of acid Lugol's solution. The cysts were then counted in a Sedgewick-Rafter cell together with the active ciliates, as described above.

Expt 4. Encystment response. A stock culture of strain M10, which had been kept in WC/Volvic with $10 \% \mathrm{SE}$ at $22 \pm 2^{\circ} \mathrm{C}$ for several weeks, was used in this experiment. Initial cell concentrations were 215 ciliates $\mathrm{ml}^{-1}$ and $3.6 \times 10^{4}$ cryptomonads $\mathrm{ml}^{-1}$. Three $20 \mathrm{ml}$ aliquots of this culture were diluted each with $40 \mathrm{ml}$ of different culture media: (1) WC/Volvic, (2) WC/Volvic containing $10 \% \mathrm{SE}$, and (3) WC/Volvic containing $10 \% \mathrm{SE}$ and $3.6 \times 10^{4}$ cryptomonads $\mathrm{ml}^{-1}$. This procedure resulted in a $1 / 3$ reduction of ciliate, food and SE concentrations in mixture 1 , of ciliate and food concentrations in mixture 2, and of only ciliate concentrations in mixture 3. Initial cell concentrations were determined in $3 \mathrm{ml}$ aliquots from these mixtures. The stock culture and the diluted cultures were then distributed into 24 -well tissue culture test plates $\left(1.5 \mathrm{ml} \mathrm{well}^{-1}\right)$. A set of 4 plates, filled with $6 \times 1.5 \mathrm{ml}$ of the stock culture and $12 \times 1.5 \mathrm{ml}$ of each of the diluted cultures, was incubated at $22 \pm 2^{\circ} \mathrm{C}$. An identical set of plates was incubated at $10 \pm 1^{\circ} \mathrm{C}$ without prior temperature adaptation. After $24 \mathrm{~h}$, the contents of each well were fixed with a small droplet of acid Lugol's solution. Numbers of active ciliates and suspended cysts were determined in a Sedgewick-Rafter chamber, while the attached cysts were counted in situ. The percentage of encysted ciliates in each well was calculated from these data. A t-test (Sigmastat, Jandel Scientific) was applied to compare results of different mixtures (= treatments).

Expt 5. Excystment response. Stock cultures of strain E4 in biphasic medium were used in this experiment. $60 \mathrm{ml}$ of the supernatant were mixed with WC/Volvic and cryptomonads to make up $200 \mathrm{ml}$ of experimental culture with 16 ciliates $\mathrm{ml}^{-1}$ and 32 cryptomonads $\mu^{-1}$. Five 24-well culture plates were filled with $1.5 \mathrm{ml}$ aliquots of this culture; previously, 150 to $200 \mathrm{mg}$ SGS had been added to some of the wells. The ciliates were allowed to grow and produce cysts at $18 \pm 2^{\circ} \mathrm{C}$ for $5 \mathrm{~d}$; the culture-fluid with the active ciliates was then removed from the wells and the remaining attached cysts were rinsed with Volvic. Cyst numbers deter-

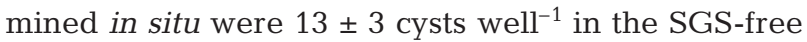
wells; cysts in the SGS-containing wells were not quantified. The plates were then stored under different conditions (wet at $10 \pm 1^{\circ} \mathrm{C}$ or dry at $22 \pm 2^{\circ} \mathrm{C}$ ) over periods from 0 to $31 \mathrm{~d}$. Subsequently, excystment tests were performed by adding WC/Volvic and food $\left(\sim 10^{4}\right.$ cryptomonads $\mathrm{ml}^{-1}$ ) to the wells; in addition, some wells received $10 \% \mathrm{SE}$ or $100 \mathrm{mg}$ SGS. After incubation at $18 \pm 2^{\circ} \mathrm{C}$ for $27 \mathrm{~h}$, numbers of active ciliates in each well were determined by live counts.

\section{RESULTS}

\section{Growth with different concentrations of soil extract (SE)}

The development of Meseres corlissi differed dramatically in batch cultures with and without SE in the culture medium. In Expt 1, growth rates during the first $24 \mathrm{~h}$ were $1.88 \pm 0.26 \mathrm{~d}^{-1}$ with $10 \%$ SE and $1.15 \pm 0.09 \mathrm{~d}^{-1}$ without SE (Fig. 3). After $3 d$, ciliate concentrations in the cultures without $\mathrm{SE}$ were $<1$ cells $\mathrm{ml}^{-1}$. In the cultures with $\mathrm{SE}$, in contrast, ciliate numbers had reached a maximum of $565 \pm 15$ cells $\mathrm{ml}^{-1}$. Within the next $3 \mathrm{~d}$, however, these populations also collapsed.
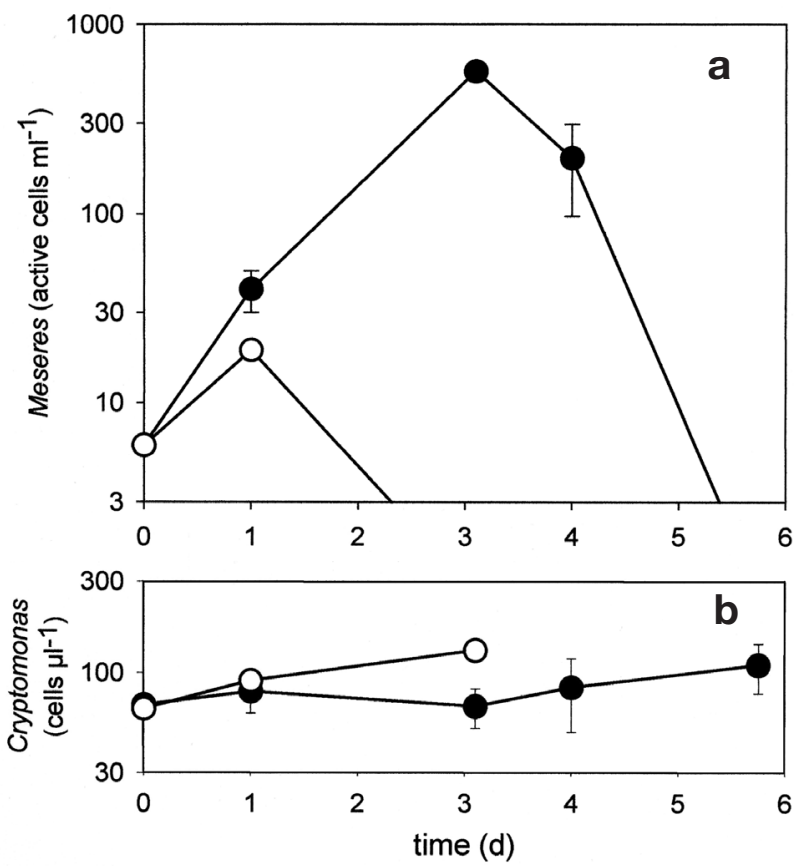

Fig. 3. Meseres corlissi. Changes of cell concentrations vs. time in batch cultures; mean values and standard deviations of 3 replicates (Expt 1). (a) Meseres Corlissi; (b) Cryptomonas sp. (@) Culture medium with $10 \%$ SE (soil extract); (O) culture medium without SE 
Fig. 4. Meseres corlissi. Changes of cell concentrations vs. time in triplicate batch cultures (Expt 2). (a) Meseres corlissi; (b) Cryptomonas sp. (๑) Culture medium with $10 \%$ $\mathrm{SE}_{\text {; }}(\mathrm{O})$ culture medium with $5 \% \mathrm{SE}_{i}$ dotted lines: culture medium without SE

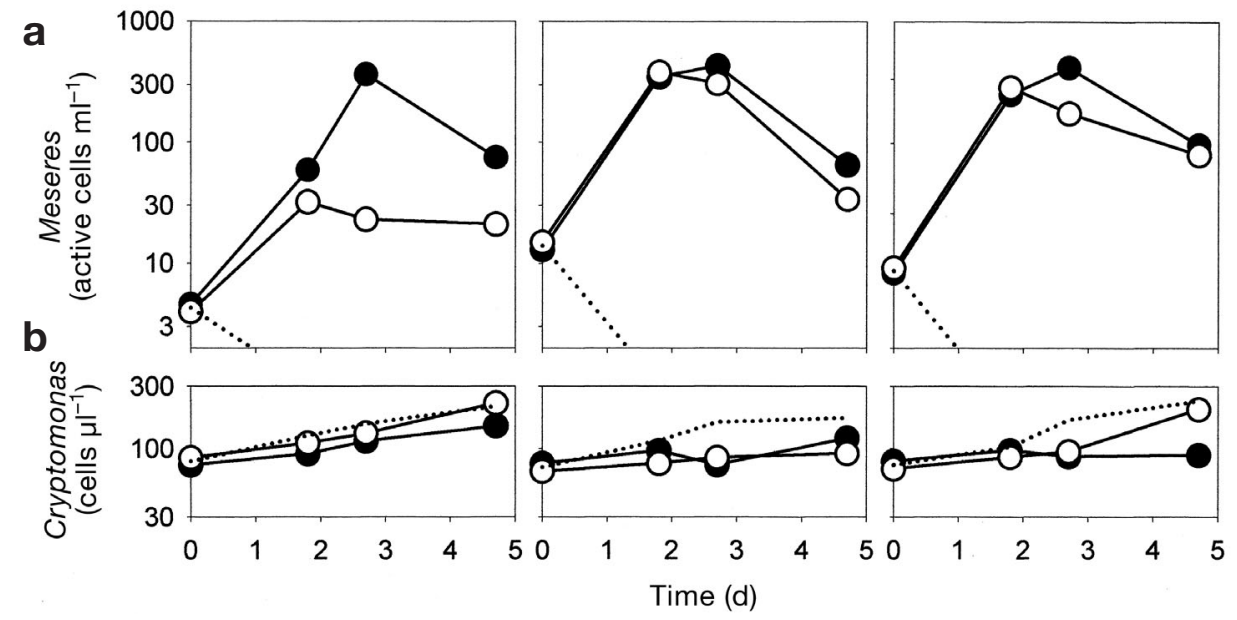

Expt 2 was started on Day 4 by taking subsamples from the 3 SE-containing cultures of Expt 1, which at this time had ciliate concentrations of 86,279 and 227 cells ml ${ }^{-1}$, respectively. These subsamples served to inoculate 3 sets of new batch cultures $(2 \mathrm{ml}$ inoculate for each $40 \mathrm{ml}$ culture) with 0,5 and $10 \% \mathrm{SE}$, respectively, in the culture medium. Population development in these 3 sets of cultures showed the same pattern (Fig. 4), despite considerable differences in initial ciliate concentrations. In the cultures without $\mathrm{SE}$, active ciliates declined to very low numbers during the first $43 \mathrm{~h}$. Over the same period, ciliate growth rates were $1.58 \pm 0.40 \mathrm{~d}^{-1}$ in cultures with $5 \%$ SE and $1.64 \pm$ $0.18 \mathrm{~d}^{-1}$ in cultures with $10 \% \mathrm{SE}$; these values were not significantly different. The decline of the active populations started $1 \mathrm{~d}$ earlier in the cultures with $5 \% \mathrm{SE}$ compared to those with $10 \%$ SE.

Notably, food concentrations increased slightly in all cultures of both experiments over the entire experimental time. The observed decline of the active populations of Meseres corlissi, therefore, cannot be explained by food limitation. Instead, our data indicate that the limiting resource was components of the soil extract, which were used up during population growth. These unknown water-soluble soil components will be referred to as the 'soil factor' in the following text.

Meseres corlissi cysts appeared in all cultures of both experiments. According to a rough estimate, their numbers were much higher in the cultures with SE than in those without SE, which is not surprising considering the much smaller and shorter-lived populations in the latter. Exact numbers of the cysts, which were mostly attached, could not be determined (see 'Materials and methods'). The experiments, therefore, do not yield information on the extent to which the breakdown of the active populations was due to encystment or mortality.

\section{Growth in the presence or absence of sterilized garden soil (SGS)}

Expt 3 was designed to study the effect of continuous input of the 'soil factor' to the culture medium. Population development in experimental and control dishes was basically different (Fig. 5). In the cultures without
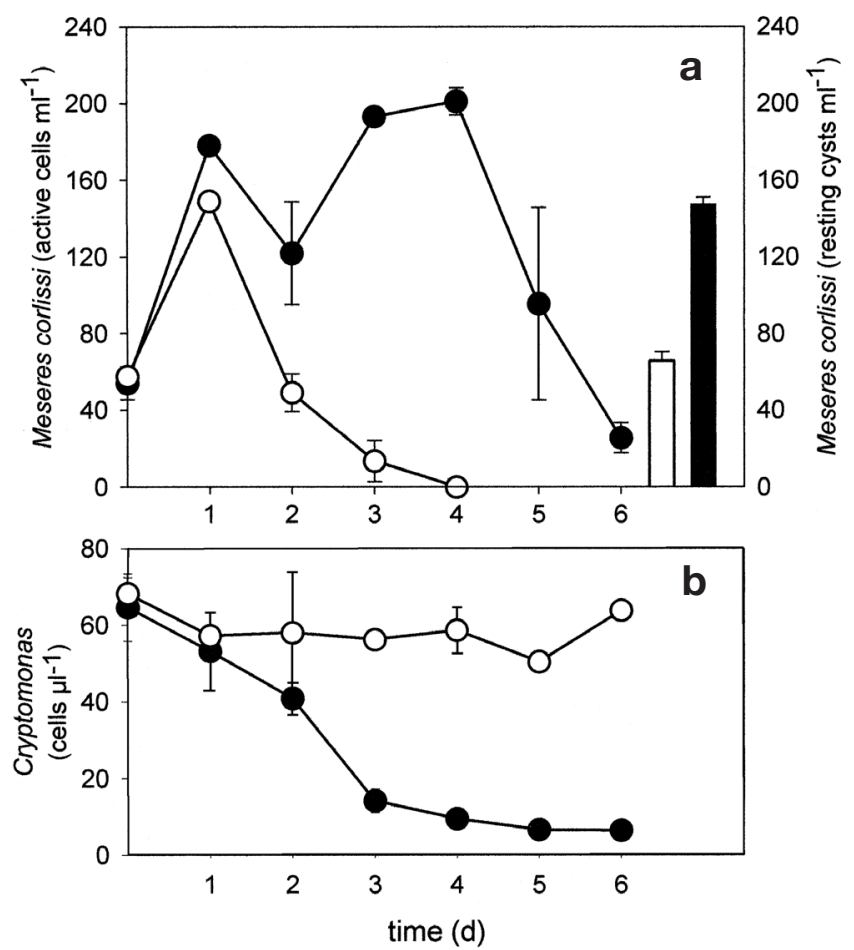

Fig. 5. Meseres corlissi. Changes of cell concentrations vs. time in batch cultures; mean values and standard deviations of 2 replicates (Expt 3). (a) Meseres corlissi; (b) Cryptomonas sp. Vertical bars show final cyst concentrations and standard deviations of 2 replicates. () and black bar: with SGS; (O) and open bar: without SGS 
Table 1. Meseres corlissi. Expt 3. Total cyst numbers and ratio of cysts:active ciliates. The ratio was calculated from hypothetical values of mean daily cyst production (cysts $\mathrm{ml}^{-1} \mathrm{~d}^{-1}$ ) and mean numbers of active ciliates (cil ml-1), averaged over the experimental time 0 to $6 \mathrm{~d}$

\begin{tabular}{|llcccc|}
\hline Culture & Treatment & $\begin{array}{c}\text { Total } \\
\text { Cysts ml } \mathrm{I}^{-1}\end{array}$ & $\begin{array}{c}\text { Cysts } \\
\mathrm{ml}^{-1} \mathrm{~d}^{-1}\end{array}$ & $\begin{array}{c}\text { Mean } \\
\mathrm{Cil} \mathrm{ml}^{-1}\end{array}$ & Cysts:active ciliates \\
\hline A & Without soil & 69 & 11.5 & 39.3 & 0.29 \\
B & Without soil & 62 & 10.3 & 33.2 & 0.31 \\
C & With soil & 150 & 25.0 & 133.4 & 0.19 \\
D & With soil & 145 & 24.2 & 131.9 & 0.18 \\
\hline
\end{tabular}

dilution of ciliates, cryptomonads and $\mathrm{SE}$ was recorded after $24 \mathrm{~h}$ incubation of $1.5 \mathrm{ml}$ aliquots at $22^{\circ} \mathrm{C}$ (Table 2). The response was weak, relative to the original culture, when either only ciliates or ciliates and algae had been diluted, while the SE level had been kept constant. The results for treatments 1 and 2 were similar, which indicates that reduction of algal con-

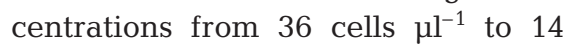
cells $\mu \mathrm{l}^{-1}$ had no major effect on the encystment reaction. In contrast,

SGS, the pattern was similar to the pattern observed in Expts 1 and 2, with population growth during the first $24 \mathrm{~h}$ (up to 150 ciliates $\mathrm{ml}^{-1}$ ) and subsequent decline. Food concentrations in the controls decreased slightly during the phase of ciliate growth, then remained stable at a level of $57 \pm 7$ cells $\mu^{-1}$. In the cultures with SGS, in contrast, the ciliate populations increased over $4 \mathrm{~d}$ (with an intermediate loss phase during the time interval 24 to $48 \mathrm{~h}$ ) to a maximum of about 200 ciliates $\mathrm{ml}^{-1}$. In the same time interval, cryptomonad concentrations decreased to $9 \pm 2$ cells $\mu l^{-1}$; during the subsequent phase of ciliate decline, they were further reduced to $6 \pm 2$ cells $\mu^{-1}$.

Cysts appeared in all cultures after 1 to $2 \mathrm{~d}$. Final cyst numbers (determined after $6 \mathrm{~d}$, see 'Materials and methods') in the SGS-containing cultures exceeded those in the controls by a factor of 2 . Relative to mean numbers of active ciliates, however, cyst production was higher in the control populations (Table 1).

\section{Encystment response}

Mass encystment was frequently observed in stock cultures of the Meseres corlissi strains after addition of SE-free culture medium and food. In Expt 4, this effect was studied under controlled conditions. The encystment response of strain M10 to an approximate 1:3 encystment was enhanced greatly in treatment 3, with an approximate 1:3 dilution of the SE concentration.

An identical set of culture plates was incubated for $24 \mathrm{~h}$ at $10^{\circ} \mathrm{C}$ instead of $22^{\circ} \mathrm{C}$. The effects of this sudden drop in temperature are summarized in Table 2 . In the original culture and all 3 treatments, the share of cysts in aliquots incubated at $10^{\circ} \mathrm{C}$ was significantly lower than in the parallel aliquots incubated at $22^{\circ} \mathrm{C}$ ( $t$-test: $\mathrm{p}<0.005)$. The temperature effect was most striking in treatment 3 , with $45 \pm 6 \%$ cysts and $3 \pm 1 \%$ cysts recorded at $22^{\circ} \mathrm{C}$ and $10^{\circ} \mathrm{C}$, respectively. The sums of active and encysted cells in treatment 3 at the high and low temperature $\left(85 \pm 12\right.$ at $22^{\circ} \mathrm{C}$ and $89 \pm 20$ cells well ${ }^{-1}$ at $10^{\circ} \mathrm{C}$ ), were not statistically different ( $t$-test: $\mathrm{p}=0.49$ ) and the total ciliate population did not decline during the $24 \mathrm{~h}$ of incubation.

\section{Excystment response}

The excystment responses in relation to the duration of dormancy and the presence or absence of SE or SGS were studied in Expt 5 (Table 3). Plate 1 was tested immediately after removal of the active ciliates; the cysts in this plate were 1 to $4 \mathrm{~d}$ old. Plate 2 was filled with Volvic and tested after $7 \mathrm{~d}$ of storage at $10^{\circ} \mathrm{C}$ in the dark. In both plates, the excystment responses to culture medium with or without soil components were

Table 2. Meseres corlissi. Expt 4. Mean cell numbers in $1.5 \mathrm{ml}$ aliquots of an undiluted culture of strain M10 and in 3 different treatments. Initial cell and SE concentrations, and concentrations of active and encysted ciliates after $24 \mathrm{~h}$ incubation in 24 -well plates at $22^{\circ} \mathrm{C}$ and at $10^{\circ} \mathrm{C}$ (see text). Treatment 1: dilution of ciliates, Treatment 2: dilution of ciliates and algae, Treatment 3: dilution of ciliates, algae and SE

\begin{tabular}{|c|c|c|c|c|c|c|c|c|c|}
\hline & \multicolumn{3}{|c|}{ Initial concentrations } & \multicolumn{3}{|c|}{ After incubation at $22^{\circ} \mathrm{C}$} & \multicolumn{3}{|c|}{ After incubation at $10^{\circ} \mathrm{C}$} \\
\hline & $\begin{array}{l}\text { Ciliates } \\
\left(\text { cells ml }^{-1}\right)\end{array}$ & $\begin{array}{l}\text { Cryptomonads } \\
\quad \text { (cells } \mu \mathrm{l}^{-1} \text { ) }\end{array}$ & $\begin{array}{l}\mathrm{SE} \\
\%\end{array}$ & $\begin{array}{l}\text { No. of } \\
\text { wells }\end{array}$ & $\begin{array}{l}\text { No. of ciliates } \\
\text { well }^{-1} \pm \mathrm{SD}\end{array}$ & $\begin{array}{c}\% \text { cysts } \\
\pm \mathrm{SD}\end{array}$ & $\begin{array}{l}\text { No. of } \\
\text { wells }\end{array}$ & $\begin{array}{l}\text { No. of ciliates } \\
\text { well }^{-1} \pm \text { SD }\end{array}$ & $\begin{array}{c}\% \text { cysts } \\
\pm \mathrm{SD}\end{array}$ \\
\hline Undiluted & 215 & 36.4 & $\sim 10$ & 6 & $246 \pm 31$ & $22 \pm 2$ & 6 & $282 \pm 39$ & $6 \pm 2$ \\
\hline Treatment 1 & 85 & 35.6 & $\sim 10$ & 12 & $108 \pm 11$ & $6 \pm 1$ & 12 & $88 \pm 11$ & $3 \pm 2$ \\
\hline Treatment 2 & 88 & 14.1 & $\sim 10$ & 12 & $112 \pm 20$ & $7 \pm 2$ & 12 & $98 \pm 11$ & $3 \pm 1$ \\
\hline Treatment 3 & 84 & 11.5 & $\sim 3$ & 12 & $85 \pm 12$ & $45 \pm 6$ & 12 & $89 \pm 20$ & $3 \pm 1$ \\
\hline
\end{tabular}


Table 3. Meseres corlissi. Expt 5. Excystment responses to different test media, measured $27 \mathrm{~h}$ after addition of the trigger by live counts of active ciliates well ${ }^{-1}$. Initial cyst numbers were $13 \pm 3$ cysts well $^{-1}$ in the SGS-free wells. Cyst numbers in the SGScontaining wells of plates 3 to 5 (not quantified) probably exceeded those in the SGS-free wells (see text)

\begin{tabular}{|c|c|c|c|c|c|}
\hline $\begin{array}{l}\text { Plate } \\
\text { no. }\end{array}$ & $\begin{array}{c}\text { Period of } \\
\text { dormancy }(d)\end{array}$ & $\begin{array}{l}\text { Conditions during } \\
\text { dormancy }\end{array}$ & $\begin{array}{l}\text { Medium tested to } \\
\text { trigger excystment }\end{array}$ & $\begin{array}{l}\text { No. of } \\
\text { wells }\end{array}$ & $\begin{array}{l}\text { Excystment response: } \\
\text { active ciliates well }{ }^{-1} \pm \mathrm{SD}\end{array}$ \\
\hline \multirow[t]{3}{*}{1} & \multirow[t]{3}{*}{$1-4$} & Excystment tests were per- & WC/Volvic/Crypt & 8 & $0.4 \pm 0.7$ \\
\hline & & formed immediately after & WC/Volvic/Crypt + SE & 8 & $15.9 \pm 7.2$ \\
\hline & & removal of the active ciliates & WC/Volvic/Crypt + SGS & 8 & $17.4 \pm 7.0$ \\
\hline \multirow[t]{3}{*}{2} & \multirow[t]{3}{*}{$8-11$} & Wet in Volvic at $10^{\circ} \mathrm{C}(7 \mathrm{~d})$ & WC/Volvic/Crypt & 8 & 0 \\
\hline & & Wet in Volvic at $10^{\circ} \mathrm{C}(7 \mathrm{~d})$ & WC/Volvic/Crypt + SE & 8 & $17.4 \pm 5.4$ \\
\hline & & Wet in Volvic at $10^{\circ} \mathrm{C}(7 \mathrm{~d})$ & WC/Volvic/Crypt + SGS & 8 & $23.1 \pm 9.9$ \\
\hline \multirow[t]{3}{*}{3} & \multirow[t]{3}{*}{$8-11$} & Dry at $21-24^{\circ} \mathrm{C}(7 \mathrm{~d})$ & WC/Volvic/Crypt & 8 & $0.1 \pm 0.3$ \\
\hline & & Dry at $21-24^{\circ} \mathrm{C}(7 \mathrm{~d})$ & WC/Volvic/Crypt + SE or SGS & 7 & $3.6 \pm 3.0$ \\
\hline & & Dry in SGS at $21-24^{\circ} \mathrm{C}(7 \mathrm{~d})$ & WC/Volvic/Crypt & 7 & $8.9 \pm 4.7$ \\
\hline \multirow[t]{3}{*}{4} & \multirow[t]{3}{*}{$15-18$} & Dry at $21-24^{\circ} \mathrm{C}(14 \mathrm{~d})$ & WC/Volvic/Crypt & 8 & 0 \\
\hline & & Dry at $21-24^{\circ} \mathrm{C}(14 \mathrm{~d})$ & WC/Volvic/Crypt + SE or SGS & 8 & 0 \\
\hline & & Dry in SGS at $21-24^{\circ} \mathrm{C}(14 \mathrm{~d})$ & WC/Volvic/Crypt & 8 & $8.4 \pm 7.0$ \\
\hline \multirow[t]{3}{*}{5} & \multirow[t]{3}{*}{$32-35$} & Dry at $21-24^{\circ} \mathrm{C}(31 \mathrm{~d})$ & WC/Volvic/Crypt & 8 & 0 \\
\hline & & Dry at $21-24^{\circ} \mathrm{C}(31 \mathrm{~d})$ & WC/Volvic/Crypt + SE or SGS & 8 & 0 \\
\hline & & Dry in SGS at $21-24^{\circ} \mathrm{C}(31 \mathrm{~d})$ & WC/Volvic/Crypt & 8 & $8.0 \pm 5.3$ \\
\hline
\end{tabular}

strikingly different. Less than 1 active ciliate well ${ }^{-1}$ appeared when only WC/Volvic with food was added, whereas on average 16 to 23 ciliates well ${ }^{-1}$ were recorded when the test medium also contained SE or SGS.

Test plates 3, 4 and 5 were air-dried and stored for 7 , 14 and $31 \mathrm{~d}$, respectively, at $22 \pm 2^{\circ} \mathrm{C}$. In the SGS-free wells of test plate 3 (dry for $7 \mathrm{~d}$ ) the excystment response was weak after addition of only WC/Volvic with food and intermediate after addition of medium containing SE or SGS. In the SGS-free wells of test plates 4 and 5 (dry for 14 and $31 \mathrm{~d}$, respectively), no excystment occurred, irrespective of the test medium. In test plates 3 to 5, a strong excystment response was recorded only in those wells to which SGS had been added at the start of the experiment. Initial cyst numbers in the SGS-containing wells could not be determined. They probably exceeded those in the SGS-free wells, as can be deducted from cyst formation in Expt 3 in the presence and absence of SGS.

\section{DISCUSSION}

\section{Soil-water culture media}

The use of soil or soil extract as a component of culture media for algae and protozoa was introduced about 70 yr ago (Föyn 1934, Pringsheim 1946). With this technique, several marine and freshwater organ- isms could be cultivated for the first time. Drawbacks of the method are that its success depends on the quality of the selected soil, and that we know little about the interactions between soil components and cultivated organisms. In the meantime, great progress has been achieved in the cultivation of algae and protozoa in fully synthetic media. Nevertheless, professional culture collections, e.g. CCAP (the Culture Collection of Algae and Protozoa at the Scottish Association for Marine Science, Dunstaffnage, Scotland), UTEX (the Culture Collection of Algae at the University of Texas, USA) and SAG (the Culture Collection of Algae at the University of Göttingen, Germany) still use soilcontaining media in special cases. Recent information by SAG on culture media for algae (www.epsag.unigoettingen.de/html/culturemedia.html) includes the statements that 'some strains cannot be grown in defined media, but only in soil-water media' and that 'the addition of soil extract often helps to achieve the typical morphology best'.

The use of soil-water media in the present study resulted in a black-box approach. Since the nature of the proposed 'soil factor' is unknown, its exact concentration in the culture media could not be determined. Our data analysis, therefore, was restricted to comparison of cultures which were started with identical inoculates. Despite these methodical problems, our approach yielded clear evidence for the impact of soil components on different phases of the life history of the Meseres corlissi type population. 
Identification of the nature of the 'soil factor' was beyond the scope of the present study. In this article, we use the term for the sum of water-soluble soil components supporting ciliate development either directly or in form of bacterial metabolites.

\section{‘Soil factor' effects}

Our data clearly demonstrate that the 'soil factor' supports growth and excystment of Meseres corlissi, whereas decreasing 'soil factor' levels trigger encystment. They also indicate that the 'soil factor' is consumed during population growth. In Expts 1 and 2 (Figs. $3 \& 4$ ), the length of growth periods in parallel cultures depended on the initial SE level. Subsamples taken from the declining cultures of Expt 1 (Fig. 3), which were used as inoculates for Expt 2 (Fig. 4), gave rise to exponentially growing cultures when provided with fresh SE. Likewise, in our normal culturing routine vegetative growth could be maintained over months by transferring the active ciliates to fresh SEcontaining medium and food at appropriate intervals.

In Expt 3 (Fig. 5) ciliate growth in the control cultures was also limited by the 'soil factor', whereas in the experimental cultures, which received continuous input of water-soluble soil components, the limiting factor was food availability. (The short loss phase recorded on Day 2 might have been caused by a temporary decrease in the soil factor level, the initial input of $10 \% \mathrm{SE}$ being depleted and the soil-components from the SGS-filled cylinder not yet fully available.)

The encystment response to decreasing 'soil factor' levels is most obvious in Expt 4 at $22^{\circ} \mathrm{C}$ (Table 2). The percentage of cysts was low in treatments 1 and 2 and high in treatment 3, while an intermediate value was recorded in the undiluted culture. The initial SE level in the undiluted culture was similar (though not identical) to that in treatments 1 and 2, whereas initial ciliate concentrations exceeded those in the diluted treatments by a factor of 3 , which probably resulted in a more rapid depletion of the 'soil factor'. This mechanism could explain ciliate encystment due to 'crowding', as frequently reported in the literature (Corliss \& Esser 1974, and references therein). Additional evidence for encystment as a response to sinking 'soil factor' levels is provided by Expt 3, in which the ratio of cysts : active ciliates was higher in the control cultures compared to the cultures receiving continuous input of soil components (Table 1).

Excystment in response to the 'soil factor' was studied in Expt 5. Cysts which had been stored in a wet state for 1 to $11 \mathrm{~d}$ reacted strongly to this trigger (Table 3, test plates 1 and 2). Numbers of active ciliates recorded after $27 \mathrm{~h}$ slightly exceeded the initial cyst numbers, probably due to division of some of the excysted ciliates during the incubation time. The responses to SE and SGS did not differ significantly. In contrast, cysts stored in a dry state for $7 \mathrm{~d}$ (in the absence of soil) reacted only weakly to SE or SGS, and those desiccated for 14 and $31 \mathrm{~d}$ did not respond at all (Table 3, plates 3 to 5). In sum, the results of Expt 5 indicate that (1) the 'soil factor' provided by SE or SGS was a powerful trigger for excystment, and (2) Meseres cysts formed in the presence of soil survived much longer periods of desiccation than those produced in the absence of soil. Based on these findings, a technique was developed to store cysts of laboratory strains of Meseres corlissi in dry soil, where they remained viable for up to 6 mo $(\mathrm{H}$. Müller unpubl.). In a dried soil sample from the type locality, field cysts of $M$. corlissi survived for ca. 2 yr $(\mathrm{H}$. Müller unpubl.).

All 'soil factor' effects documented here for one of the Salzburg strains were also observed, in similar experiments, in the other strain under investigation (data not shown). Differences in the responses of strains M10 and E4 were too small to be detected with the methods used in the present study.

At the beginning of this study, stock cultures of both strains were maintained, with some difficulties, in SE-free medium. Under these conditions, growth rates were low and growth was interrupted by frequent loss phases. Mass encystment occurred especially after addition of fresh culture medium. However, in completely encysted populations, 'spontaneous' excystment of a few ciliates was occasionally observed after days, weeks or months of dormancy. This could be due to varying concentrations of bacterial metabolites with similar qualities as the 'soil factor', a hypothesis which needs to be tested experimentally.

\section{Other factors controlling en- and excystment}

It is widely accepted that the most common stimulus leading to ciliate encystment is starvation (Fenchel 1987, Gutiérrez et al. 2001). However, encystment due to food depletion, a well known response in colpodid and hypotrich ciliates, has not been unequivocally demonstrated in any of the oligotrich species which have been investigated to date. In field studies, cyst formation at the end of a bloom period has been recorded for Strombidium crassulum (Reid 1987), Helicostomella subulata (Paranjape 1980), Cyrtostrombidium boreale (Kim et al. 2002), S. viride and Pelagostrombidium fallax (Müller \& Wünsch 1999), but it is not clear whether starvation was the inducing factor. In the latter study, the first cysts were recorded when prey concentrations were still high. Cyst forma- 
tion of $P$. fallax in the laboratory occurred at high and low food levels, but was enhanced during phases of decreasing prey abundance (Müller 1996, 2000). The tintinnid $H$. subulata, when grown in the laboratory on a diet of microflagellates with the food always in excess, encysted irrespective of food concentrations (Paranjape 1980).

Our data on Meseres corlissi agree with these findings. In Expts 1 and 2 and in the control cultures of Expt 3 food concentrations were high throughout the experiments; nevertheless, large numbers of cysts were produced. In the SGS-containing cultures of Expt 3 the first cysts also appeared at high food concentrations, though we cannot exclude that cyst production was enhanced during the period of food depletion. In Expt 4 (treatment 2) a drastic reduction of algal concentrations had no effect on the encystment reaction. In short, we found no significant relationship between encystment and food availability, in agreement with observations of Weisse (2004), who reported that the impact of food concentration on cyst formation was low in strain DR (from the Dominican Republic) of M. corlissi.

Significant relationships between encystment and/or excystment and temperature have been reported for several oligotrich ciliates (Paranjape 1980, Kim \& Taniguchi 1995, 1997, Kim et al. 2002, Müller 2002, Weisse 2004). The present study contains little evidence for such a relationship. The encystment rate of strain M10 was negatively affected by a sudden temperature decrease (Expt 4, Table 2), a result which may be explained by the reduced metabolic rate of the ciliates at $10^{\circ} \mathrm{C}$, such that the $\mathrm{SE}$ in the culture medium was not used up. Excystment of field cysts from dry soil could be triggered, by addition of fluid, at $10^{\circ} \mathrm{C}$ and $22^{\circ} \mathrm{C}$ (H. Müller unpubl.). Other external factors which might influence en- or excystment, such as light conditions, changes in ionic concentrations of the culture medium or the impact of predators, were not investigated.

Intrinsic factors which might influence en- and excystment of Meseres corlissi were not identified in the present study. We did not observe obligatory encystment after a defined number of cell divisions, and we can rule out that cyst formation was related to conjugation, since conjugation never occurred in our clonal strains. Obligatory excystment related to cyst age was described by Müller (2002) for Pelagostrombidium sp. In this species, all individuals excysted spontaneously, without an apparent external trigger, after $>3$ mo of dormancy. In contrast, spontaneous excystment of Meseres corlissi occurred only occasionally and irrespective of cyst age and, therefore, was most likely due to environmental changes (see above: 'Soil factor' effects').

\section{Comparison with the bromelia population}

The first ecological study of Meseres corlissi (Weisse 2004) was performed with an isolate originating from the reservoir of a tree bromelia Guzmania ekmanii in a fog rain forest near Santiago, Dominican Republic. This isolate (strain DR) was morphologically and genetically (in several gene regions, SSU rDNA, ITS1 and ITS2) indistinguishable from the Salzburg strains (Foissner 2005, Foissner et al. 2005, M. C. Strüder-Kypke unpubl.). Stock cultures of strain DR were maintained in the laboratory for more than $2 \mathrm{yr}$, using basically the same methods as described in the present study, except that no soil or soil extract was added to the culture medium. Much to our regret, strain DR declined at the same time at which strains M10 and E4 were isolated from the type locality, which impeded simultaneous experiments with strains from both habitats. Nonetheless, comparison of published data on strain DR (Weisse 2004) with observations on the Salzburg strains (this study) reveals interesting differences.

Strain DR grew at high rates (up to $2.8 \mathrm{~d}^{-1}$ at $25^{\circ} \mathrm{C}$, Weisse 2004) relative to other oligotrich ciliates studied under similar experimental conditions (Montagnes 1996 and references therein, Müller \& Schlegel 1999, Gismervik 2005, Weisse \& Rammer 2006) and relative to the Salzburg clones investigated in the present study. Growth rates of strain M10 recorded in Expt 1 at $22.5^{\circ} \mathrm{C}$ were $1.88 \pm 0.26 \mathrm{~d}^{-1}$ in cultures with $\mathrm{SE}$, which is not different from growth rates of the DR strain recorded in cultures without $\mathrm{SE}$ at the same temperature and with the same algal food $\left(1.78 \pm 0.39 \mathrm{~d}^{-1}\right.$, Weisse 2004). It appears, therefore, unlikely that growth of strain DR could have been enhanced further by addition of soil extract to the culture medium. We conclude that strain DR, unlike the Salzburg strains, did not depend on soil components for optimal growth.

Weisse (2004) investigated cyst formation of strain DR relative to temperature and food concentration by counting suspended cysts together with the active ciliates under different culture conditions. This method could be used since in strain DR, in contrast to strains M10 and E4, the majority of the cysts was not attached to the culture dishes. While the impact of food concentration was low, a highly significant negative relationship between cyst formation of strain DR and temperature was recorded, with the fraction of cysts increasing dramatically at temperatures $\leq 20^{\circ} \mathrm{C}$. Furthermore, a rise in temperature from 15 to $24^{\circ} \mathrm{C}$ was found to induce excystment (Foissner et al. 2005). We observed the opposite effect in strain M10 (Expt 4 of the present study). While at $22^{\circ} \mathrm{C}$ encystment could be induced by diluting the SE concentration in the culture medium, this response was impeded by a sudden drop in temperature from 22 to $10^{\circ} \mathrm{C}$. 


\section{CONCLUSIONS}

In its natural habitat, a temperate astatic meadow pond, the type population of the oligotrich ciliate Meseres corlissi lives in close contact with soil. In laboratory experiments, using 2 clonal isolates from this site, we observed that soil extract in the culture medium supported growth and excystment, while a decrease in its concentration (by either dilution or consumption) triggered encystment of active, not foodlimited populations. Resting cyst survived larger periods of desiccation only when formed in the presence of soil. These results suggest that the $M$. corlissi type population, in all phases of its life cycle, strongly depends on a 'soil factor', i.e. water-soluble soil components and/or their bacterial metabolites, the nature of which remains at present unknown.

The morphologically and, with respect to the SSU rDNA and ITS gene regions, genetically indistinguishable Meseres corlissi population encountered in the Dominican Republic lives in the reservoirs of a tree bromelia, which contain only small quantities of soil. The strain originating from this population did not depend on soil components for optimal growth, and its encystment-excystment cycle was mainly controlled by temperature (Weisse 2004). Obviously, habitat requirements may differ considerably within this species. Our results point to the importance of local adaptation among geographically distant populations of a cosmopolitan, but rare, ciliate species.

Acknowledgements. We thank Ulrike Scheffel and Peter Stadler for skilled technical assistance. This study was financially supported by the Austrian Science Foundation (FWF), project P16796-B06.

\section{LITERATURE CITED}

Corliss JO, Esser SC (1974) Comments on the role of the cyst in the life cycle and survival of free-living protozoa. Trans Am Microsc Soc 93:578-593

Fauré-Fremiet E (1948) Le rythme du marée du Strombidium oculatum Gruber. Bull Biol France-Belgique 82:3-23

Fenchel T (1987) Ecology of protozoa. The biology of free-living phagotrophic protists. Science Tech Publishers, Madison, WI

Foissner W (2005) The unusual, lepidosome-coated resting cyst of Meseres corlissi (Ciliophora: Oligotrichea): transmission electron microscopy and phylogeny. Acta Protozool 44:217-230

Foissner W, Agatha S, Berger H (2002) Soil ciliates (Protozoa, Ciliophora) from Namibia (Southwest Africa), with emphasis on two contrasting environments, the Etosha region and the Namibia desert. Denisia 5:1-1459

Foissner W, Müller H, Weisse T (2005) The unusual, lepidosome-coated resting cyst of Meseres corlissi (Ciliophora, Oligotrichea): light and scanning electron microscopy, cytochemistry. Acta Protozool 44:201-215

Föyn B (1934) Lebenszyklus, Cytologie und Sexualität der Chlorophycee Cladophora Suhriana Kützing. Arch Protistenkd 83:1-56

Editorial responsibility: Karel Šimek, České Budějovice, Czech Republic
Gismervik I (2005) Numerical and functional responses of choreo- and oligotrich planktonic ciliates. Aquat Microb Ecol 40:163-173

Guillard RRI, Lorenzen CJ (1972) Yellow-green algae with chlorophyllide C. J Phycol 8:10-14

Gutiérrez JC, Callejas S, Borniquel S, Benitez L, MartinGonzales A (2001) Ciliate cryptobiosis: a microbial strategy against environmental starvation. Int Microbiol 4: 151-157

Jonsson PR (1994) Tidal rhythm of cyst formation in the rock pool ciliate Strombidium oculatum Gruber (Ciliophora, Oligotrichida): A description of the functional biology and an analysis of the tidal synchronization of encystment. J Exp Mar Biol Ecol 175:77-103

Kim YO, Taniguchi A (1995) Excystment of the oligotrich ciliate Strombidium conicum. Aquat Microb Ecol 9:149-156

Kim YO, Taniguchi A (1997) Seasonal variation of excystment pattern of the planktonic oligotrich ciliate Strombidium conicum. Mar Biol 128:207-212

Kim YO, Suzuki T, Taniguchi A (2002) A new species in the genus Cyrtostrombidium (Ciliophora, Oligotrichia, Oligotrichida): its morphology, seasonal cycle and resting stage. J Eukaryot Microbiol 49:338-343

Montagnes DJS (1996) Growth responses of planktonic ciliates in the genera Strobilidium and Strombidium. Mar Ecol Prog Ser 130:241-254

Montagnes DJS, Wilson D, Brooks SJ, Lowe C, Campey M (2002) Cyclical behaviour of the tide-pool ciliate Strombidium oculatum. Aquat Microb Ecol 28:55-68

Müller (1996) Encystment of the freshwater ciliate Pelagostrombidium fallax (Ciliophora, Oligotrichida) in laboratory culture. Aquat Microb Ecol 11:289-295

Müller H (2000) Evidence of dormancy in planktonic oligotrich ciliates. Verh Int Verein Limnol 27:3206-3209

Müller H (2002) Laboratory study of the life cycle of a freshwater strombidiid ciliate. Aquat Microb Ecol 29:189-197

Müller H, Schlegel A (1999) Responses of three freshwater planktonic ciliates of different feeding modes to cryptophyte and diatom prey. Aquat Microb Ecol 17:49-60

Müller H, Wünsch C (1999) Seasonal dynamics of cyst formation of pelagic strombidiid ciliates in a deep prealpine lake. Aquat Microb Ecol 17:37-47

Müller H, Stadler P, Weisse T (2002) Seasonal dynamics of cyst formation of strombidiid ciliates in alpine Lake Mondsee, Austria. Aquat Microb Ecol 29:181-188

Paranjape MA (1980) Occurrence and significance of resting cysts in a hyaline tintinnid, Helicostomella subulata (Ehre.) Jorgensen. J Exp Mar Biol Ecol 48:23-33

Petz W, Foissner W (1992) Morphology and morphogenesis of Strobilidium caudatum (Fromentel), Meseres corlissi n. sp., Halteria grandinella (Müller), and Strombidium rehwaldi n. sp., and a proposed phylogenetic system for oligotrich ciliates (Protozoa, Ciliophora). J Protozool 39: 159-176

Pringsheim EG (1946) The biphasic soil-water culture method of growing algae or flagellata. J Ecol 33:193-204

Reid PC (1987) Mass encystment of a planktonic oligotrich ciliate. Mar Biol 95:221-230

Weisse T (2004) Meseres corlissi: a rare oligotrich ciliate adapted to warm water and temporary habitats. Aquat Microb Ecol 37:75-83

Weisse T, Rammer S (2006) Pronounced ecophysiological clonal differences of two common freshwater ciliates, Coleps spetai (Prostomatida) and Rimostrombidium lacustris (Oligotrichida), challenge the morphospecies concept. J Plankton Res (in press)

Submitted: October 25, 2005; Accepted: December 16, 2005 Proofs received from author(s): January 27, 2006 